\title{
Disrupting the grassroots narrative of social work in Aotearoa New Zealand
}

Sonya Hunt, Barbara Staniforth, Liz Beddoe, University of Auckland, Aotearoa New Zealand

\begin{abstract}
INTRODUCTION: The Aotearoa New Zealand social work professionalisation project disrupted underpinning grassroots narratives of the profession and led to decades of debate and conflict. Social work emphasises egalitarian approaches and, during the 1980s and 1990s, social workers responded to internal and external challenges of elitism, racism, and sexism. However, the ongoing professionalisation project has been at times, at odds with social justice imperatives and undermined by neoliberal drivers.
\end{abstract}

METHODS: This research investigated how political, sociocultural and economic dimensions impacted on the development and initial implementation of the Social Workers Registration Act (2003) and how key actors at the time were affected. A qualitative realist research methodology has been utilised, analysing qualitative interviews with 22 participants, policy documents and archival data to clarify discourses of power and capture the voices and rich stories of those involved in the debates at the time.

FINDINGS: A sociological lens was utilised to focus and frame the coalescing political, socio-cultural and economic forces that contributed to the problematising of social work professionalisation and the determining of the need for registration. Insight from some key actors at the time, including educators, the profession, tangata whenua, employers, practitioners, the State, and the public were considered.

CONCLUSIONS: Examining these forces behind the professionalisation project provides a platform to consider if social work in Aotearoa New Zealand has been strengthened with registration. There are ongoing challenges and threats to the independence and social justice focus of the profession that grew alongside the grassroots of social work.

KEYWORDS: Social work professionalisation; social work regulation; Aotearoa New Zealand; social worker registration; social justice; neoliberalism
Me hoki whakamuri, kia ahu whakamua, kaneke

In order to improve, evolve, and move forward, we must reflect back on what has been

This Māori whakatauki/ proverb considers the importance of remembering and critically reflecting upon our past in order to progress effectively.

It is useful to begin examination of this part of the history of social work in Aotearoa with an exploration of professionalisation, a process by which an occupational group aspires to professional status - shared internally and recognised externally
AOTEAROA

NEW ZEALAND SOCIAL WORK 32(1), 45-60.

CORRESPONDENCE TO: Sonya Hunt sonyahunt@xtra.co.nz 
(Beddoe, 2013; Evetts, 2006; Hunt, 2016, 2017; Olgiati, 2006). Internationally and in Aotearoa New Zealand over the decades up to the early 2000s, social work professionalisation projects gained traction (Weiss-Gal \& Welbourne, 2008). These projects were politically charged, requiring strategic alliances, the evidencebased demonstration of social workers' technical knowledge and competence, the development of ethical standards, and differentiation of social work from competing and overlapping groups. Many actors became involved, including the profession, education providers, the State, employing organisations, practitioners and the public. In Aotearoa New Zealand, indigenous people and corresponding Treaty of Waitangi/ Te Tiriti O Waitangi ${ }^{i}$ obligations also played a part. Together, the professionalisation and regulation projects in Aotearoa New Zealand appeared to disrupt the social work narrative of grassroots social justice strategies in local communities (Munford \& Walsh-Tapiata, 2006). The projects remain open to critique because of the risk of undermining core grassroots social work values and ethos, along with the autonomy and creativity of service and education providers (Beddoe, 2018; Hunt, Staniforth, \& Beddoe, 2019; O'Brien, 2005; van Heugten, 2011). In this article, we consider different political, sociocultural and economic dimensions that, together, determined the direction of the professionalisation and regulation projects, from the perspective of some of the participants at the time of the development and implementation of social worker registration.

\section{Methods}

The research was conducted as part of a doctoral study project that aimed to answer the following question:

In what ways have political sociocultural and economic dimensions impacted on the development and initial implementation of the Social Workers Registration Act (SWRA) (2003) in Aotearoa New Zealand?

Qualitative realist research methodologies were utilised, analysing interviews, policy documents and archival data to explore discourses of power and enable the voices of the stakeholders from this time to be articulated and recorded. The combination of qualitative methods used served to offer validity of the analysis through the processes of crystallisation (Richardson, 1994) and triangulation of qualitative methods (Cohen, Manion, \& Morrison, 2011). Themes from the data were conceptualised, coded, and analysed utilising NVivo software and a recursive process of theme development (Braun \& Clarke, 2016). Several ethical considerations were managed including the researcher's insider role, and the identification of the inaugural Social Workers Registration Board (SWRB) members. These 10 participants consented to being identified in the research and are named in the article, while the other, unnamed, participants were assured their identities would not be revealed. Ethics approval was obtained from The University of Auckland's Human Participants Ethics Committee.

\section{Findings}

The research found that grassroots approaches to social work in Aotearoa New Zealand were gradually disrupted over decades. Many forces together problematised and determined social work professionalisation in Aotearoa New Zealand. Problematising as opposed to problem solving, is the regrading of a phenomenon into a problem requiring a solution and is integral to critical consciousness providing sites of resistance and hope (Giroux, 2015). Participants close to the action at the time of social work registration development described their lived experiences, including the 'toing and froing' of the journey, the ambivalence of some and the outright opposition of others, due at least in part to issues within 
social work in Aotearoa New Zealand that first required addressing alongside changing socio-cultural, political, and economic forces.

The forces that problematised and determined social work professionalisation are summarised thematically and within each theme chronologically in Table 1: Aotearoa New Zealand social work professionalisation project brief timeline (see below). They are then discussed in more detail following the same outline.

Table 1. Aotearoa New Zealand Social Work Professionalisation Project Brief Timeline

\begin{tabular}{|c|c|c|}
\hline \multirow[t]{2}{*}{ Early days } & $\begin{array}{l}\text { Pre } 1840 \text { \& } \\
\text { Te Tiriti o } \\
\text { Waitangi (1840) }\end{array}$ & $\begin{array}{l}\text { Māori models of welfare in context of whānau, hapū and iwi (Durie, 1997; Nash, 2009) } \\
\text { expressed in practices associated with tikanga and kaupapa. English and Māori language } \\
\text { versions of Te Tiriti o Waitangi signed 1840, providing protection \& governance but not } \\
\text { (according to Māori version) ceding sovereignty (Fleras \& Spoonley, 1999; Beddoe, 2018). }\end{array}$ \\
\hline & $\begin{array}{l}\text { Late } 1800 \text { s \& } \\
1900 \text { s }\end{array}$ & $\begin{array}{l}\text { Developing western models of social work in a colonial state, reflecting British education, } \\
\text { policing, child welfare, criminal justice \& mental health systems (Beddoe, 2018; Nash, } \\
\text { 2001; Tennant, 1989). }\end{array}$ \\
\hline \multirow[t]{7}{*}{$\begin{array}{l}\text { Collective occupation, } \\
\text { burgeoning profession }\end{array}$} & 1964 & $\begin{array}{l}\text { New Zealand Association of Social Workers (NZASW) formed providing a collective } \\
\text { social work professional identity \& linking regional branches; membership voluntary; } \\
\text { consideration of who is a social worker. }\end{array}$ \\
\hline & 1970 s \& 80s & $\begin{array}{l}\text { Social workers' internal ambivalence re professionalising apparent within NZASW. } \\
1976 \text { Biennial Conference moved that the Association "accept the principle of registration } \\
\text { and further investigations be carried out into this matter." } \\
\text { The Christchurch branch Working Party on Registration Report (1977). }\end{array}$ \\
\hline & $1984-86$ & $\begin{array}{l}\text { NZASW conferences in Christchurch (1984) and Turangawaewae, Waikato (1986), } \\
\text { challenges of racism leading to constitutional change. }\end{array}$ \\
\hline & 1988 & $\begin{array}{l}\text { Professional drive for best practice \& accountability-competency based membership and } \\
\text { self-regulation process for members through formal complaints mechanism. }\end{array}$ \\
\hline & 1994 & NZASW re-considers models of regulation (Blagdon, Taylor, \& Keall, 1994). \\
\hline & 1999 & $\begin{array}{l}31 \text { May: Registration Project Team Terms of Reference finalised with following purpose } \\
\text { "On behalf of Aotearoa New Zealand Association of Social Workers (ANZASW)' to develop } \\
\text { policies on registration for social workers and to implement planning steps and strategies, } \\
\text { within association policy, towards ultimate achievement of registration for all social work } \\
\text { practitioners on Aotearoa New Zealand." }\end{array}$ \\
\hline & 2000 & $\begin{array}{l}\text { Groundswell in profession supporting registration including tangata whenua members } \\
\text { (Corrigan et al., 2000). }\end{array}$ \\
\hline \multirow[t]{6}{*}{$\begin{array}{l}\text { Growth in education \& } \\
\text { training }\end{array}$} & 1949 & $\begin{array}{l}\text { Establishment of first formal tertiary social work education \& training in Aotearoa New } \\
\text { Zealand at Victoria University of Wellington, School of Social Science. }\end{array}$ \\
\hline & 1973 & $\begin{array}{l}\text { Establishment of social work training and education accreditation with } \\
\text { - New Zealand Social Work Training Council (NZSWTC) (est. June 1973); }\end{array}$ \\
\hline & 1986 & $\begin{array}{l}\text { - New Zealand Council for Education and Training in the Social Services (NZCETSS) } \\
\text { (est. December 1986); }\end{array}$ \\
\hline & 1995 & $\begin{array}{l}\text { - Industry Training Organisation Te Kai Awhina Ahumahi (TKA) for National Diploma in } \\
\text { Social Services (Social Work) and National Diploma in Social Work (est. 1995); } \\
\text { - New Zealand Qualifications Authority (NZQA) for degree programmes awarded by } \\
\text { Polytechnics, Colleges of Education or Private Training Establishments; } \\
\text { - Committee on University Academic Programmes (CUAP) - degree and diploma } \\
\text { programmes; }\end{array}$ \\
\hline & 2003 & - ANZASW Course Approvals process combined with CUAP or NZQA. \\
\hline & 1996 & $\begin{array}{l}\text { Linking of social work educators through an Aotearoa New Zealand Association of Social } \\
\text { Work Educators (ANZASWE) later to become known as the Council for Social Work } \\
\text { Educators Aotearoa New Zealand (CSWEANZ). }\end{array}$ \\
\hline
\end{tabular}




\section{QUALITATIVE RESEARCH}

\begin{tabular}{|c|c|c|}
\hline \multirow[t]{7}{*}{ Political dimensions } & 1990 & $\begin{array}{l}\text { Fourth National Government elected with general anti-profession ethos. Minister of Social } \\
\text { Welfare, Roger Sowry, convinced regulation of social workers necessary and money } \\
\text { allocated to DSW budget for development. }\end{array}$ \\
\hline & 1991 & $\begin{array}{l}\text { 'Mother of all budgets' - result of growing neoliberal, market-driven environment in } \\
\text { Aotearoa New Zealand that developed from the fourth Labour Government 1984-1990. }\end{array}$ \\
\hline & 1990s & $\begin{array}{l}\text { Increasing loss of faith in social work by State and public as a result of growing public } \\
\text { scrutiny of failures in child protection. } \\
\text { Regulation viewed by the State as a safety net. }\end{array}$ \\
\hline & 1999 & $\begin{array}{l}\text { Labour Party manifesto pledged to establish a system of professional registration for social } \\
\text { workers (New Zealand Parliament, 2003). } \\
\text { 5th Labour Government elected, political sponsorship for registration secured (Maharey, } \\
\text { 1998). }\end{array}$ \\
\hline & 2000 & $\begin{array}{l}\text { State steps in with discussion paper on registration of social workers (Ministry of Social } \\
\text { Policy, 2000, 2001). }\end{array}$ \\
\hline & 2002 & $\begin{array}{l}\text { Social Workers Registration Bill and select committee process (Social Services Select } \\
\text { Committee, 2002). }\end{array}$ \\
\hline & 2003 & $\begin{array}{l}\text { Social Workers Registration Act (2003): providing for voluntary registration of social } \\
\text { workers with purpose outlined in (s.3) to protect the public; create a framework for } \\
\text { registration of social workers in NZ establishing a board \& tribunal; promote the benefits of } \\
\text { registration of social workers; enhance the professionalism of social workers. }\end{array}$ \\
\hline \multirow[t]{10}{*}{$\begin{array}{l}\text { Employer challenges: } \\
\text { DSW }\end{array}$} & $1 / 4 / 72$ & $\begin{array}{l}\text { Department of Social Welfare (DSW) })^{\mathrm{il}} \text { formed from the amalgamation of the Social } \\
\text { Security Department and the Child Welfare Division of the Department of Education. }\end{array}$ \\
\hline & 1984 & Department of Social Welfare (1984) Institutional Racism in the DSW Report. \\
\hline & 1988 & $\begin{array}{l}\text { Department of Social Welfare (1988) Püao-te-Āta-tü: The Daybreak Report, identified } \\
\text { structural inequality \& racism in DSW, leading to sweeping changes in child welfare \& } \\
\text { youth services \& the Children Young Persons \& their Families Act (1989). }\end{array}$ \\
\hline & $1990-00 s$ & $\begin{array}{l}\text { Environment of growing aversion to risk, public shaming and apportioning of blame for } \\
\text { poor practice and child abuse tragedies, and corresponding growth in audit and control. }\end{array}$ \\
\hline & 1992 & $\begin{array}{l}\text { Mason Report (1992) noted dangerously low levels of professionally trained social workers } \\
\text { in DSW. }\end{array}$ \\
\hline & $1990 \mathrm{~s}$ & $\begin{array}{l}\text { Margaret Bazley (Director General DSW) facing issues of under-competence in her } \\
\text { organisation promoted regulation to Minister of Social Welfare, Roger Sowry. }\end{array}$ \\
\hline & 1990s & DSW workforce professionalising policy - targets never met. \\
\hline & 1990s & DSW establish an internal competency programme in lieu of registration. \\
\hline & 1996 & $\begin{array}{l}\text { New Zealand Children \& Young Persons Service (CYPS) documented professionalisation } \\
\text { strategic goal (New Zealand Children and Young Persons Service, 1996). }\end{array}$ \\
\hline & 2000 & $\begin{array}{l}\text { Mick Brown report (Brown, 2000) recommending that registration of the Child Youth and } \\
\text { Family Service (CYFS) workforce be given urgency. }\end{array}$ \\
\hline \multirow[t]{2}{*}{$\begin{array}{l}\text { Employer challenges: } \\
\text { Health }\end{array}$} & 1990 s & $\begin{array}{l}\text { Rapid growth in health social work with drive to employ qualified staff \& align with } \\
\text { multidisciplinary health professionals. }\end{array}$ \\
\hline & 1990s & Development of Health Social Work Leaders network. \\
\hline \multirow[t]{2}{*}{ Practitioner voices } & 1980s & $\begin{array}{l}\text { Tangata whenua practitioners lead challenges of racism in practice and in the profession. } \\
\text { Issues of registration, professionalism and racism become intertwined (Fraser \& Briggs, } \\
\text { 2016). }\end{array}$ \\
\hline & $1990 \mathrm{~s}$ & $\begin{array}{l}\text { Rapid growth of NGO sector including Iwi Social Services. } \\
\text { NGO and State sector developing bicultural frameworks for practice referencing Te Tiriti O } \\
\text { Waitangi as baseline for services. }\end{array}$ \\
\hline
\end{tabular}




\begin{tabular}{|l|l|}
\hline 1999-2000s & $\begin{array}{l}\text { The concept of registration of social workers to embed bicultural practice as determined by } \\
\text { Māori was re-introduced by tangata whenua leaders in the profession while remembering } \\
\text { the historical journey and hard-won battles. }\end{array}$ \\
\hline 2000 s & $\begin{array}{l}\text { Pasifika practitioners view registration as pathway to recognise and embed Pacific models } \\
\text { of practice. }\end{array}$
\end{tabular}

' NZASW changed its name in 1998 to Aotearoa New Zealand Association of Social Workers (ANZASW) to reflect its bicultural priority. ii Statutory child protection and welfare services in Aotearoa New Zealand have undergone a number of reviews, Ministerial reshuffles, rebranding, and name changes. Since 31 October 2017, it is known as Oranga Tamariki - Ministry for Children. Previously it was known as the Ministry for Vulnerable Children (Oranga Tamariki) (April 2017-October 2017); Child Youth and Family (CYF) (2006-2017); Child Youth and Family Services (CYFS) (1999-2006); Children and Young Persons Service (CYPS) (1992-1999); Department of Social Welfare (DSW) (1972-1992); Social Security Department (1939-1972) and the Child Welfare Division of the Department of Education (1925-1972).

\section{Early days}

Durie (1997) outlined early Māori models of welfare in the context of whānau, hapu and iwi and expressed in practices associated with tikanga and kaupapa that operated effectively prior to the arrival of new settlers from Britain. English and Māori language versions of The Treaty of Waitangi / Te Tiriti o Waitangi, signed in 1840, provided protection and governance but did not (according to Te Tiriti version) cede sovereignty (Fleras \& Spoonley, 1999). With growing colonial settlement, western models of social work developed from the mid- to late-1800s in response to the limited social and economic capital of the new arrivals, reflecting, to a degree, British education, policing, child welfare, criminal justice and mental health systems (Beddoe, 2018; Nash, 2001; Tennant, 1989; Younghusband, 1981).

\section{A collective occupation and burgeoning profession}

Nash and Miller (2013) note the establishment of a professional body (alongside the development of education and training which is discussed in the next section), signalled the emerging profession of social work. This history of the New Zealand Association of Social Workers (NZASW) was recalled by a participant who had been in practice during this time:

When I started my service in 1960, the people we now call social workers were all individual groups of either Government workers or non-Government workers, ... child welfare officers, boys' welfare officers, probation officers.... It was after the [Department of Social Welfare] Act, (1971) that created the Department and defined social worker for the first time, that we began to think of ourselves as belonging to a larger group of collective people doing pretty much the same sorts of things as us but in different practice areas...earlier, Merv Hancock ${ }^{\mathrm{ii}}$ moved to get the Association going. [And we had] the beginning of social work training at Victoria University under Professors Minn and McCreary. (Participant C, February 21, 2017)

The topic of registration was raised at the outset of the establishment of a professional association in 1964 (NZASW, 1984b, June) and revisited throughout the decades with many different views.

Merv Hancock talked about registration right from when the Association started, and successive presidents have talked about that...it was around the profession growing up and being independent of sociology and psychology. A way of doing that is to have its own regulatory environment (John Dunlop, June 13, 2016).

Following a proposal by the NZASW

National Executive in 1974, that a membership register of individual members be developed (Nash, 1998), the Christchurch Branch of NZASW established a working 
party in 1977 to consider registration. Their report recommended immediate steps be taken towards registration of eligible social workers, acknowledging implementation would require a staged approach, or failing this, that a new body be established to undertake registration (Christchurch Branch, NZASW Working Party on Registration, 1977). The recommendations were debated at the 1978 NZASW Special General Meeting alongside the Biennial Conference where the keynote speaker, Ivan Illich, focused on the disabling professions, arguing against professionalism (Illich, 1978). Despite the 'Illich effect' (M. McKenzie, personal communication March 26, 2019), and following revisions from the original recommendations, a motion that "the Executive of NZASW establish a register of qualified social workers and determine the criteria by which Association members be admitted to the register" was carried: 69 for, 34 against (NZASW SGM meeting minutes, August 9, 1978).

However, Kendrick (2004, p. 12) recalled:

... at the 1978 conference in Palmerston North, with its guest speaker Ivan Illich, a strong debate took place on a registration proposal which had been worked on during the past year. I recall this debate as emotionally charged on both sides, and the word "elitism" featured prominently. The [original] motion was lost, but looking back on the nature of the time, that was not an unexpected outcome.

Buster Curson (July 12, 2016) similarly recalled that the original proposal developed by the committee "ultimately lost favour because it was regarded as being elitist". Within a few years, another branch was pushing for registration and the NZASW Professional Standards Committee included many members of this branch.

... there was a very strong group in Hawkes Bay...that was very proregistration... wanted qualifications, wanted registration...in the 80s.

(Liz Beddoe, May 18, 2016)
Nonetheless, the professional body needed to focus on other internal issues in order to retain and grow membership. These included challenges of elitism due to access to training, feminist challenges around misuse of power, and challenges of racism within the profession including recognition of the profession's colonising role. Following on from the Human Rights Commission (1982) 'Race against time' report into institutionalised discrimination, NZASW established a working party on racism in 1984. The same year, nine women employed by DSW as social workers made public issues of institutional racism in DSW in Tamaki Makaurau in the Women against Racism Action Group (WARAG) report stating "the institutional framework of the Department, staffing training, legislation, policies, reflects a relentlessly Pākehā view of society, which oppressively and systematically discriminates against the interests of consumers and staff who are Māori and Pacific people" (Berridge et al., 1984, para 1.2.). This report was a forerunner to, and acknowledged in, the seminal Pūao-te-Āta-tū: The Daybreak Report (Department of Social Welfare, 1986).

Fraser and Briggs (2016) document turbulent times in the profession in the 1980s where "issues of registration, professionalism and racism became intertwined" (p. 44) culminating in 1986 at the NZASW conference at Turangawaewae Marae, Waikato. Here, a draft Bi-cultural Code of Practice developed by the NZASW Standing Committee on Racism along with the Association itself were rejected by Māori social workers who did not speak but turned their backs and walked out. Later, in 1987, the tangata whenua caucus announced their decision to "stand alone and gather their strength and resources before looking at partnership ... in NZASW" (Fraser \& Briggs, 2016, p. 46); the caucus did not return to NZASW until 1989. In response, NZASW developed a new bicultural structure and a Qualification in Social Work Practice (QSWP) (later becoming the 
ANZASW Competency Certificate), where full membership required assessment of competence to practise and not qualification (Beddoe \& Randal, 1994). The competency assessment was available through two parallel pathways, with tangata whenua members developing the Niho Taniwha competency process:

[we] had already discussed the name of it with John Bradley, and he said, Niho Taniwha...he said it's about the teeth... Niho Taniwha was given to ANZASW so that Māori could use it, to use their own culture when they look at the 10 standards and that was the strength of it. (Participant D, July 11, 2016)

Registration to enhance the safety of the public, increase the status of the profession and promote accountability for all social workers, whether they were members of the association or not, was again ready for reconsideration by the Association and social work sector. The Association set up another working party to consider types of registration of social workers and information was collated on types of occupational regulation to encourage informed debate and develop terms of reference (Blagdon, Taylor, \& Keall, 1994). The ANZASW Registration Special Project Team, formally established in May 1999, found that statutory regulation was the preferred option as it would include all practising social workers and reduce the risk to the professional body as the accountability of its members would be removed from its mandate (Corrigan et al., 2000).

The profession had for many years been pushing for a regulatory body and ... I think that was around them not wanting to have to be the quasi regulatory body by doing all of the complaint procedures and having to hold social workers to account; which was an intensive task and given the litigiousness within our society ... it was better for the Association not to have to be that body. (John Dunlop, June 13, 2016)
A major matter of contention was deciding who could claim the title of social worker in the diverse social services sector. People held a range of qualifications from social-work-related diplomas and degrees through to work and life experience. It was acknowledged, through professional and organisational competency processes, that grassroots life experiences usually resulted in 'good work' in many communities.

However, claiming the title of social worker by some workers was clearly a public and professional safety issue. The following quotes demonstrate the complex issues regarding the assurance of recognised qualifications, while respecting the practice of longstanding, but unqualified, practitioners.

There were issues that required the profession to be regulated because there were a number of practitioners without the skills and knowledge... and that was having adverse impacts on the population...[them] calling themselves social workers was one of the biggest issues for the profession. (Participant $\mathrm{H}$, April 30, 2017)

... there was that need for having a vehicle for social workers to claim their profession and for there to be mechanisms and the structure for the public to know what that means. (Shannon Pakura, August 8, 2016)

...because we were a profession, and we had cowboys coming in and doing shoddy practice,... but we were also saying "what does that mean to our nanas who have been working in the social services?" (Participant L, November 6, 2017)

We had earlier discussions about professionalisation and whether this is a good thing, whether it's culturally relevant, elitist, and of course in Aotearoa [with] the very strong emphasis on de-colonising practices...there was [much] discussion about what does social work 
represent?, how do we respond to the client groups that we were working with?, how do services ensure that practice is consistently good?, questions of quality. (Participant B, January 25, 2017)

While protecting the public from poor practice was the driver for registration for many stakeholders, for the profession itself, registration provided a pathway for professional validation.

They [saw the need] for the profession to stand up and be seen as being equal to other professions... to be seen as strong and influential, not just a ragbag of people wanting to do good things. (Shannon Pakura, August 8, 2016).

[ANZASW saw registration as an opportunity to] to validate the status of the profession ... that's the bottom line. The Association's driver was more about validation than protection. (Buster Curson, July 12, 2016).

the purpose, from [ANZASW's] point of view, was to align social work as a profession with other regulated professions, I'm not too sure that the safety of the public was the prime driver at that time (Robyn Corrigan, September 23, 2016).

\section{Growth in social work education and training}

Educators were at the forefront of debates considering the professionalisation of social work from the instigation of the first social work qualification, the Diploma in Social Sciences at Victoria University (Nash \& Miller, 2013). The process for social work training and education accreditation changed over the decades with the establishment of the New Zealand Social Work Training Council (NZSWTC), later replaced by the New Zealand Council for Education and Training in the Social Services (NZCETSS), and then Te Kai Awhina Ahumahi (TKA)
(Beddoe, 2014). These organisations expanded social work education and strengthened the view that social work was a generic occupation, albeit with specific fields of practice.

At the same time ANZASW was becoming stronger, Te Kai Awhina Ahumahi...linked alongside, and social work became to be seen as something that was generic because Presbyterian social workers were no longer seen as completely different from Departmental social workers; if they were doing their job well. Yes, so that is where the registration came [from]. It is a natural development isn't it? (Participant F, November 14, 2016)

In 1996, social work educators set up a body providing a unifying voice for social work educators, initially the Aotearoa New Zealand Association of Social Work Educators (ANZASWE), later the Council for Social Work Education of Aotearoa New Zealand (CSWEANZ)/Kaunihera mo ngā Mahi Mātauranga Toko I te Ora. The society met to promote, among other things, the scholarly pursuit of teaching, research and publication within social work programmes in accordance with Te Tiriti O Waitangi. Further it aimed to promote and support collaboration across social work, social services and community work education, maintain close relationships within the social work sector including with professional bodies and advocate for the needs and resourcing of the education sector (CSWEANZ, 2014).

Educators considered different models of registration including whether it may have been better for the profession, mandated by the State, to be the regulator to avoid the risk of capture of the profession by State imperatives.

...we also had a discussion about whether it should have been ANZASW who were mandated by Government to form the Registration Board...because [we] had 
experience with the Australian scene where it was the profession who did the approvals [of programmes]. (Participant K, December 1, 2016)

The educators were generally supportive of a measured introduction to mandatory registration recognising that many practising social workers did not have formal social work qualifications.

... in general, the educators were in favour of registration...we had discussions with senior [Ministry] people. They were anxious about registration because they had so many people who were unqualified...so we were for a slow implementation and for that special clause [section 13] where... people who had other qualifications plus experience and references, could get [registered]. Underlying our comments always were, let us try and find a way of making this mandatory but not instantly mandatory. (Participant K, December 1, 2016)

With the implementation of the Social Workers Registration Act (2003), consultation with educators regarding baseline qualifications and the required standard content across the range of qualifications was required (Hunt et al., 2019).

It raised challenges for educators of social workers to buy into the notion of professionalisation...what is an initial social work training? where does that lead to? what is an adequate body of knowledge? That was a big problem for educators...because when you've got a semi-profession you have a wildly different approach to what constitutes a fully trained person. (Participant $\mathrm{G}$, July 11, 2016)

\section{Political dimensions: State voice}

With the very public exposure of practice issues relating to child abuse deaths, and reports that criticised social work practice (for example, Brown, 2000; Mason, 1992), there was a growing awareness by the State, employers, and public that social work was not a regulated profession with expected minimum standards. While child protection social work represented one field of social work, the media focused on blame following child abuse tragedies and a corresponding loss of faith in social work developed for the State and public. Some politicians and their chief executives sought professionalisation opportunities for social work in order to reduce risk for their portfolios, as well as to protect the vulnerable.

One of the purposes and justifications for the SWRA (2003) is that it's a bullet proof vest for the Government. That when tragedies occur, when things go wrong and social workers are at the heart of what's been happening, whether their practice is exemplary or not, the social workers are registered... the Act [would] provide Ministers with a 'get out of jail' card. (Shannon Pakura, August 8, 2016)

...it was a political response to the unfortunate deaths of children; there was criticism of social work,...this is not peculiar to New Zealand,... because [it] is so...socially difficult, emotionally, morally, politically, ethically contentious. (Liz Beddoe, May 18, 2016)

The political environment in the 1980s and 1990s was complex - with ideological debates mixed with pragmatism. In 1990, the fourth National Government was elected that was generally anti-professions; however, the Minister of Social Welfare, Roger Sowry was convinced that regulation of social workers was necessary:

...while [the National Government] had [an] anti-registration ethos...Roger Sowry got money for [social worker registration] and it would be in the budget of that following year. Steve Maharey [Labour Minister] gets a lot of the credit...he [should] for the law because he was the Minister [of Social Services 1999-2005] 
when the law was passed, but...he shouldn't get the credit for accepting that this was the right thing to do in the face of National's own policy. I think you can put a lot of the credit on Margaret Bazley [Director General, DSW] and her persuasive powers. (Participant C, February 21, 2017)

The opposition Labour Party supported social worker registration as part of its manifesto (Maharey, 1998) but:

...social work was pretty much a battered child during the 1990s in the sense that it became a football and was rundown and underfunded and became a very difficult place for people to work. [There were] lots of discussions; Michael [Cullen] and others,... one of the things [the Labour party] talked a lot about was it would be really good if this turned into a proper profession that had a proper status with properly trained people... (Participant G, July 11, 2016)

In 1999 when Labour won the election, Steve Maharey, the newly appointed Minister of Social Services, began the legislative process for social worker registration (Ministry of Social Policy, 2000, 2001; New Zealand Parliament, 2003; Social Services Select Committee, 2002).

I think his interest was not necessarily about the wellbeing of the profession, [rather] about the political benefits of registration and that he was the Minister shepherding it through the legislative process. (Shannon Pakura, August 8, 2016)

People [in Government were at that time] keen on re-professionalisation,...in areas like teaching and social work and a range of kind of what sociologists call semi-professions... as a device to lift the status [of the profession] but also to try and create a workforce of highly skilled and capable people... (Participant G, July 11, 2016)
Some participants also spoke about other agendas for the State to seek the registration of social workers:

At the time there were [concerns] about the management of some NGOs, where there was questionable...practice. There was a menagerie of NGOs that were being funded and registration [would] provide a mechanism to be able to downsize the sector because you [would] need to have registered social workers...to access taxpayer funding. So externally it was all about the profession - covertly there were other priorities.

...the intention of the Act was to provide the public with some confidence in the quality of the social work education. There [were also concerns about] social work education programmes; so, one of the [anticipated] outcomes from the Registration Act was a stabilising of the sector and the sector having some standards that they would have to adhere to. (Shannon Pakura, August 8, 2016)

\section{Statutory child welfare voices}

Over the decades, there had been regular challenges to the efficacy and quality of the prevailing child rescue philosophy of practice in Aotearoa New Zealand and accompanying State institutional care for children and young people.

About 1982, the Human Rights Commission reported on complaints made about the Auckland institutions [for children and young people]; and how [children] were managed and treated.... The process [of closing the Institutions] might have started because we needed money but, in the end, [there were] kids that should not have been in them anyway. [It] really raised professionalism and professional ethics and rights and that became the driver. (Participant C, February 21, 2017) 
Alongside challenges to the child rescue model, challenges of racism resulted in several reviews of child welfare (Berridge et al., 1984; Department of Social Welfare, 1986) and ultimately the development of the Children, Young Persons, \& their Families Act (1989) and the family group process.

[The new legislation created a response to the] child rescue mode of practice... as once you feature [child rescue] as the springboard for your actions, then you've got to move children out rather than move the abusers out and leave the children within that context and family system that can take hold of them. (Participant C, February 21, 2017)

Fears that the re-introduction of this model of practice might occur with the current Home for Life focusiii in Oranga Tamariki prompted the participant to reflect that:

...an apology to the people of New Zealand for the way that [social work] practice dealt with children over those 10, 20, 30 years, might have been sufficient to put the blocks on it happening again. (Participant $\mathrm{C}$, February 21, 2017)

In the 1990s, DSW attempted to increase the skill levels of its social workers though recruitment of qualified staff, continuing professional development and an internal competency process designed to ensure base-line standards for all social workers that proved costly (Keall, 1993; New Zealand Children and Young Persons Service, 1996).

[The CYPS] competency programme had proven to be an expensive failure and I think [registration] was a way of Ministers saying that we will be prepared to have an open scrutiny of the practice of social workers.

(John Dunlop, June 13, 2016)

CYPS increasingly played a key role in problematising the need for registration, as despite attempts in the 1990s to professionalise through recruitment of qualified staff, targets were never met. A State-driven strategy was required.

[CYPS had a] policy of workforce professionalising...[CYPS] would lose qualified people, particularly to the health sector who had an absolute ban on appointing anybody who wasn't qualified...What emerged... was that [CYPS] will never professionalise until social work in New Zealand had professionalised.

[Registration] never got into the formal system until we got it into [the DSW] business plan, and then it took off ... I'm absolutely sure that had DSW not done that work, the Association would not have been able to affect registration. They'd been trying for years without any inroad, and it wasn't until we got a Minister to say "yes, this will be Government policy, and yes we will fund it", that it began to move. (Participant C, February 21, 2017)

\section{Health sector voices}

Social work practice in health care had been developing since the 1940s and, by the 1990s, health social workers were seeking alignment with developing tangata whenua health services and other allied health professions in the multi-disciplinary context to strengthen their position in relation to the medical and nursing professions (Beddoe \& Deeny, 2012; Hunt \& King, 2000).

It was about strengthening the position of the profession to try and align more closely with other professions... and to maintain that whole credibility in the multi-disciplinary context of the health service. (Buster Curson, July 12, 2016)

Professional leaders were appointed to support allied health professions in the sector, including social work.

... around that time [mid 1990s], other DHBs appointed professional leaders and 
we had a first DHB social work network meeting; chaired by David McNabb. (Participant A, January 31, 2017)

While there was a general expectation that social workers employed in the health sector should hold a minimum Level B diploma ${ }^{\text {iv }}$ qualification in social work (Hunt, 2016), gaps in professional accountability mechanisms were apparent:

The [Health and Disability Commission's] Inquiry Report into the Southland District Health Board Mental Health Services identified systemic problems...including the practice of a social worker. His practice was looked at against ANZASW standards and many knew, that that [these standards] weren't recognised or mandatory as for the other professions, and yet what else could you judge someone's practice against. (Participant A, January 31, 2017)

By the 2000s, the State was introducing new legislation for health practitioners (Health Practitioners Competence Assurance [HPCA] Act, 2003) providing one consistent framework for regulating registered health professions to ensure the public is protected from harm when receiving health services. Social work was excluded from this Act, due to social work fields of practice being wider than health alone. Health social workers and the profession were determined that the proposed SWRA (2003) aligned with the HPCA Act (2003), and health social work roles would not be side-lined. As registration under the SWRA (2003) was not mandatory, health social worker status alongside their allied health peers was again under question (Briggs \& Cromie, 2001).

\section{Joining of practitioner voices}

Social workers, both Māori and non-Māori began urging one another to professionalise:

Social workers the time has come to stand up and advocate for our clients and our profession. If we do not do it now for ourselves, we will be de-professionalised into extinction. (Kieran O'Donoghue,

Newsfeed Blog 27 March 2001)

\section{Tangata whenua practitioner voices}

Parallel to the professionalisation project was the growing volume of tangata whenua voices against the impact of colonisation and racism in practice and the profession. Participants spoke about the NZASW history and the decades following when the NGO social services sector rapidly increased including the growth of Iwi social services and services by Māori for Māori. They reflected how mainstream organisations in both the NGO and the State sectors began developing bicultural frameworks of practice referencing the Treaty of Waitangi as a baseline for services. There were concerns that the social work workforce did not match the ethnic mix of New Zealand, particularly the communities of need, and the predominance of Māori as clients in health, justice, and child protection services. The concept of registration of social workers to embed bicultural practice as determined by Māori was re-introduced by tangata whenua leaders in the profession while remembering the historical journey and hard-won battles.

1985 I left university and I worked with children [in the health sector] ... I really struggled initially in that space but it was good grounding for seeing social work as significant inside the hospital setting and yet there was very little in the way of Māori voice in that space... my supervisor at the time said to me "you know,....you need to actually look at some cultural supervision". (Participant L, November 6, 2017)

[In the 90s ANZASW]...had started implementing quite strong tangata whenua processes within the organisation...I think that the Association was probably at its strongest then because of the membership and we had the Roopu up and running, which was fantastic because you just dealt with 
one [group of] people. (Participant J, December 1, 2016)

[There was a huge development around Māori contribution inside this professional space to do with tikanga, developing competency, dealing with conflict of interest, ethics...there was a whole body of knowledge worldwide, research that was being done... (Participant L, November 6, 2017)

In the late 1990s, the new millennium,... we'd had a decade in social work with the new Children, Young Persons and their Families Act (1989), ... also at that time, there had been 10 years of the growth of Iwi social services and Māori social service delivery and organisations promoting 'by Māori, for Māori' practices and processes, ... and the idea of registration was introduced into that particular...[growing] group of organisations. (Robyn Corrigan, September 23, 2016)

\section{Other voices}

Pasifika voices also contributed to the problematising of social work registration:

...we wanted our knowledge to be recognised in terms of frameworks of practice...there were Pacific models of practice, but in some way, we saw a standardisation of the social work profession as a way to ensure that those who were working with our Pasifika communities had a comprehensive enough understanding,...because everybody went to different [education] institutes,....and the knowledge was different, but it was a way for us as Pacific graduates, of protecting and acknowledging the place of Pacific practitioners and the expertise and skills. (Participant I, January 19, 2017)

Some non-government organisations (NGOs) also problematised and determined the need for registration, recognising its value to their services despite the probable financial cost to them.

The [State employers] and the profession would say that they were the main drivers [of registration], [but] some really brave employers from the NGO sector championed registration and saw the benefit, [they] led the way and made some big sacrifices: Stand, Barnados, Family Works. And even some of the smaller NGOs that really couldn't afford it but saw it more as an investment...they played the long game. (Participant $\mathrm{H}$, April 30, 2017)

The main union, the Public Service Association, specifically focused on fair treatment for all social workers in the determining of registration working to:

...make sure that its members would be treated fairly...aware that [registration] could intensify...differences in the work force where you had a considerable proportion of the work force [not] qualified.... The legislation that was coming was going to require some kind of qualification. (Liz Beddoe, May 18, 2016)

Others spoke of social work in the global context:

[A] secondary driver was about making sure that New Zealand social workers were attractive in other western jurisdictions, who had registration... (Shannon Pakura, August 8, 2016)

\section{Discussion}

It is argued that, despite the social work professionalisation project in Aotearoa New Zealand occurring during major neoliberal economic revisions, the project progressed due to the alignment of multiple factors (Hunt, 2017). The grassroots narrative of social work was increasingly disrupted through the decades through efforts by the multiple stakeholders to ensure consistent and good 
enough practice and to protect the public from poor practice. The irony of the development's timing was not lost on the participants.

...it came about at almost the same time as consumers were challenging the label of expert. So many social workers were heavily involved in the women's health movements, land marches, nuclear free NZ, promoting partnership and selfdetermination, social justice, we were quite radical community development grass-roots workers and at the same time the State lost its faith in professions and needed to challenge social workers. (Sonya Hunt, May 3, 2016)

However, the risk that a State regulator tightens rules, controls and definitions of social work, which ultimately undermine the social justice mandate of the profession is clear. Grassroots pathways into the profession are now restricted with the current requirement of a minimum four-year degree in social work to meet the qualification benchmark (Hunt et al., 2019) and the application of 'fit and proper considerations' for registered social workers (SWRB, 2018). There remains a sense of unease:

I've had a somewhat conflicted view of looking at registration, mainly because I think it has the potential to constrain innovation, and so that has always be a tension for me around the introduction of registration and who does it best suit, and does it do what we hoped it would do. (Participant B, January 25, 2017)

Social work operates in civil society, so we have bodies that set themselves up in civil society, whereas once you've got....an arm of the State, you're going to have the whole apparatus of the State imposing on you [so registered social workers have to] give up power to this process. With registration you're going to get the 'grey suited bureaucrats in Wellington', I never thought it would be me but, in a sense, I don't disagree with myself. (Liz Beddoe, May 18, 2016)

\section{Conclusions}

These personal accounts of the social work professionalisation journey illuminate the contested views and enduring struggles between stakeholders. Social workers challenged themselves to put their own house in order, demonstrating endurance and resilience as a maturing professional group. They sought to make central the views of those groups within the profession and who they served that had been marginalised, a basic of grassroots practice. Professionalisation was expected to improve services and ensure better outcomes. The SWRA (2003) provided for voluntary registration, a unique response to regulation and reflecting the State's ambivalence within a neoliberal political environment. However, following several reviews of the legislation, the Social Workers Registration Legislation Act (2019) was passed making it mandatory for all practising social workers to register by 2021.

It is important to reflect on the various agendas behind professionalisation and regulation, as well as the impacts, both intended and unintended. The ongoing development of frameworks that assert the rights of groups that may be readily marginalised including indigenous service users and practitioners, is fundamental to ensuring that difference is kept on the agenda and grassroots priorities, while disrupted, are not forgotten.

\section{Acknowledgements}

Thanks to the participants in this study, and to the SWRB and ANZASW for allowing access to their archives, and to the University of Waikato for their support of this research. Thanks to the reviewers for their thoughtful and helpful comments.

\section{Disclosure statement}

No potential conflict of interest was reported by the authors. 


\section{Notes}

i Treaty/Tiriti O Waitangi was agreed in 1840 between representatives of the British Crown and many indigenous Māori chiefs. The English and Māori versions of The Treaty/Te Tiriti hold different meanings resulting in different expectations of The Treaty's /Te Tiriti's terms and ongoing challenges for resolution.

ii Mervyn (Merv) Hancock (1926-2016), widely acknowledged as the father of modern social work in Aotearoa New Zealand was the first President of NZASW. Along with colleagues, Ephra Garret and Graeme Fraser, Merv established the four-year Massey University BSW in 1975.

iii The home for life initiative aims to reduce the amount of time children and young people spend in State care and reduce the number of placement changes they experience by transitioning children and young people from the care of Oranga Tamariki to a permanent home. https://www.orangatamariki.govt.nz/assets/ Uploads/20180614-information-about-home-for-life-andhome-for-life-achieved.pdf

iv Diploma with equivalent of two year's fulltime study.

Accepted: 20 December 2019

Published: 14 April 2020

\section{References}

Beddoe, L. (2013). A profession of faith, or a profession: Social work, knowledge and professional capital. New Zealand Sociology, 28(2), 44-63.

Beddoe, L. (2014). A matter of degrees: The role of education in the professionalisation journey of social work in New Zealand. Aotearoa New Zealand Social Work, 26(2\&3), 17-28.

Beddoe, L. (2018). Social work education in Aotearoa New Zealand: Building a profession. Practice, 30(4), 305-320. doi:10.1080/09503153.2018.1478955

Beddoe, L., \& Deeney, C. (2012). Discovering health social work in New Zealand in its published work: Implications for the profession. Aotearoa New Zealand Social Work, 24(1), 41-55.

Beddoe, L., \& Randal, H. (1994). The New Zealand Association of Social Workers: The professional response to a decade of change. In R. Munford \& M. Nash (Eds.), Social work in action (pp. 21-36). Palmerston North, New Zealand: The Dunmore Press.

Berridge, D., Cowan, L., Cumberland, T., Davys, A., McDowell, H., Morgan, J., . . . Wallis, P. (1984). Institutional racism in the Department of Social Welfare Tamaki-Makaurau. Tamaki-Makaurau, New Zealand: Department of Social Welfare.

Blagdon, J., Taylor, M., \& Keall, B. (1994). Social worker registration. Social Work Review(June), 24-25.

Braun, V., \& Clarke, V. (2016). (Mis)conceptualising themes thematic analysis, and other problems with Fugard and Potts' (2015) sample-size tool for thematic analysis. International Journal of Social Research Methodology, 19(6), 739-743. doi:10.1080/13645579.2016.1195588

Brown, M. (2000). Care and protection is about adult behaviour: The Ministerial Review of the Department of Child, Youth and Family Services. Retrieved from https://www.msd.govt.nz/documents/about-msd-andour-work/publications-resources/archive/2000-care-andprotection-is-about-adult-behaviour.pdf Wellington, New Zealand.

Briggs, L., \& Cromie, B. (2001). Editorial, Registration issues for health social work: Will social workers become second tier health professionals? Social Work Review, 13(2), 1

Children, Young Persons, \& their Families Act 1989. 1989 S.N.Z. 24.

Cohen, L., Manion, L., \& Morrison, K. (2011). Research methods in education (7th ed.). New York, NY: Routledge.

Corrigan, R., Semmons, W., Clark, K., Taylor, M. McPherson, C., Cromie, B., ... Randal, H. (2000). Statutory registration for social workers. Social Work Review, 12(1), 18-23.

Council for Social Work Education Aotearoa New Zealand. (2014) Constitution. Retrieved from http://www.csweanz. ac.nz/

Department of Social Welfare. (1986). Puao-te-ata-tu. The report of the Ministerial Advisory Committee on a Māori perspective for the Department of Social Welfare. Wellington, New Zealand: Author.

Department of Social Welfare Act, 1971, 1971 S.N.Z. No 60

Durie, M. (1997). Mana Māori Motuhake: The state of the Māori nation. In R. Miller (Ed.), New Zealand politics in transition (pp. 372-385). Auckland, New Zealand: Oxford Univerity Press.

Christchurch Branch, NZASW Working Party on Registration. (1977). Report of Working Party on Registration. New Zealand Social Work, 1(2), 54-57.

Evetts, J. (2006). Introduction: Trust and professionalism: Challenges and occupational changes. Current Sociology, 54(4), 515-531. doi:10.1177/0011392106065083

Fleras, A., \& Spoonley, P. (1999). Recalling Aotearoa: Indigenous politics and ethnic relations in New Zealand. Auckland, New Zealand: Oxford University Press.

Fraser, S., \& Briggs, L. (2016). Bi-culturalism and accountability: Fundamental changes in social work practice in Aotearoa New Zealand 1984-1990. Aotearoa New Zealand Social Work, 28(1), 43-51. doi: http://dx.doi.org/10.11157/anzswj-vol28iss1id118

Giroux, H., A. (2015). Henry Giroux on the rise of neoliberalism. Humanity \& Society, 39(4), 449-455. doi:10.1177/0160597615604985

Health Practitioners Competence Assurance Act, 2003, 2003 S.N.Z. No. 48

Human Rights Commission New Zealand. (1982). Race against time: Institutionalised discrimination. Wellington, New Zealand: Author.

Hunt, S. (2016). The social work professionalisation project before the 1990s in Aotearoa New Zealand: The dream. Aotearoa New Zealand Social Work, 28(3), 15-25. doi:http://dx.doi.org/10.11157/anzswj-vol28iss3id245

Hunt, S. (2017). The social work regulation project in Aotearoa New Zealand. Aotearoa New Zealand Social Work, 29(1), 53-64. doi:http://dx.doi.org/10.11157/ anzswj-vol29iss 1 id 370 
Hunt, S., Staniforth, B., \& Beddoe, L. (2019). Establishing the qualification criteria for social worker registration in Aotearoa New Zealand: Conflict and compromise. Social Work Education, 38(7), 894-907. doi:10.1080/02615479. 2019.1593957

Hunt, S., \& King, T. (2000). Allied health: Aligned for empowerment. Social Work Review, 12(3), 13-19.

Illich, I. (1978). The disabling professions. Paper presented at the New Zealand Association of Social Workers Biennial Conference., Massey University, Palmerston North, New Zealand

Keall, B. (1993). Biting the bullet: Professionalism. Social Work Review, 5(3), 4-6.

Kendrick, J. (2004). A national association: A reflection of its times? Social Work Review, 16(4), 7-14.

Maharey, S. (1998). Social policy, social work and professionalism. Social Work Review, 10(4), 25-26.

Mason, K. (1992). Report of the Ministerial review on the implementation of the Children, Young Persons and their Families Act 1989. Wellington, NZ: Department of Social Welfare.

Ministry of Social Policy. (2000). The registration of social workers. Retrieved from https://www.msd.govt.nz/ documents/about-msd-and-our-work/publicationsresources/archive/2000-reg_socwork_discpaper.pdf

Ministry of Social Policy. (2001). Registration of social workers: Consultation summary report. Retrieved from https://www.msd.govt.nz/documents/about-msd-and-ourwork/publications-resources/archive/2001-reg_socwork consultationsummary.pdf

Munford, R., \& Walsh-Tapiata, W. (2006). Community development: Working in the bicultural context of Aotearoa New Zealand. Community Development Journal, 41(4), 426-442. Retrieved from http://cdj.oxfordjournals.org/content/41/4/426.abstract. doi:10.1093/cdj/bsl025

Nash, M. (1998). People, policies and practice: Social Work education in Aotearoa/New Zealand from 1949-1995 (Unpublished doctoral dissertation), Massey University, Palmerston North, New Zealand. Retrieved from http://hdl.handle.net/10179/2014

Nash, M. (2001). Social work in Aotearoa, New Zealand: Its origins and traditions. In M. Connolly (Ed.), New Zealand social work: Contexts and practice (pp. 32-43). Auckland, New Zealand: Oxford University Press.

Nash, M., \& Miller, J. (2013). Social work: Where have we been and where are we going? In M. Connolly \& L. Harms (Eds.), Social work: Contexts and practice (pp. 329-345). Melbourne, Australia: Oxford University Press.

New Zealand Association of Social Workers. (1984a, February). Working Party on racism. News and views in social work.

New Zealand Association of Social Workers. (1984b, June). Discussion paper on registration. Auckland: Author.

New Zealand Children and Young Persons Service. (1996). Professionalisation strategy. Wellington, New Zealand: Author.

New Zealand Parliament. (2003). Social Workers Registration Bill - Second reading, in committee, third reading. Wellington, New Zealand: Hansard and Journals. Retrieved from http://www.parliament.nz/en-nz/ pb/debates/debates/47HansD_20030403_00001124/
social-workers-registration-bill-\%E2\%80\%94-secondreading-in-committee

O’Brien, M. (2005). A just profession or just a profession? Social work and social justice. Social Work Review, 17(1), 13-22.

Olgiati, V. (2006). Shifting heuristics in the sociological approach to professional trustworthiness: The sociology of science. Current Sociology, 54(4), 533-547. doi:10.1177/0011392106065085

Richardson, L. (1994). Writing: A method of inquiry. In N. Denzin \& Y. Lincoln (Eds.), Handbook of qualitative research (pp. 516-529). Thousand Oaks, CA: Sage.

Social Services Select Committee. (2002). Social Workers Registration Bill, Government Bill, Commentary from the select committee. Wellington, New Zealand: House of Representatives Retrieved from https://www. parliament.nz/en/pb/bills-and-laws/bills-proposed-laws/ document/00DBHOH_BILL4155_1/social-workersregistration-bill

Social Workers Registration Act 2003, 2003 S.N.Z. No. 17.

Social Workers Registration Legislation Act 2019, 2019 S.N.Z. No. 3.

Social Workers Registration Board. (2018, June). Fit and Proper Person: Policy Statement. Wellington, New Zealand: Author. Retrieved from https://swrb.govt. nz/about-us/policies/

Tennant, M. (1989). Paupers and providers: Charitable aid in New Zealand. Wellington, New Zealand: Allen \& Unwin and Historical Branch of Internal Affairs.

van Heugten, K. (2011). Registration and social work education: A golden opportunity or a Trojan horse? Journal of Social Work, 11(2 ), 174-190. doi:10.1177/1468017310386695

Weiss-Gal, I., \& Welbourne, P. (2008). The professionalisation of social work: A cross-national exploration. International Journal of Social Welfare, 17(4), 281-290. doi:10.1111/j.1468-2397.2008.00574.

Younghusband, E. (1981). The newest profession. A short history of social work. London, England: Community Care/IPC Business Press. 